\title{
MENINGKATKAN KETERAMPILAN PROSES SAINS MELALUI PENDEKATAN INKUIRI
}

\author{
Rini Susanti \\ www.facebook.com/rini.s.ranggono \\ PG PAUD FIP Universitas Negeri Jakarta
}

\begin{abstract}
Abstrak: Penelitian ini bertujuan untuk meningkatkan keterampilan proses sains anak usia 5-6 tahun melalui pendekatan inkuiri di TK Kasih Ibu, Jakarta Selatan, November dan Desember 2012. Metode yang digunakan adalah penelitian tindakan kelas yang dilakukan melalui dua siklus yang masing-masing terdiri atas perencanaan, tindakan, pengamatan, dan refleksi. Subjek penelitian adalah anak usia 5-6 tahun di TK Kasih Ibu, Jakarta Selatan yang mempunyai masalah dalam keterampilan proses sains sebanyak 12 orang. Teknik pengumpulan data menggunakan tes dan non tes. Teknik analisis data yang digunakan dalam penelitian ini adalah dengan menggunakan prosentase. Penelitian ini menyimpulkan, pendekatan inkuiri dapat meningkatkan keterampilan proses sains anak usia 5-6 tahun. Implikasi hasil penelitian ini adalah bahwa pendekatan inkuiri dapat dijadikan sebagai alternatif pembelajaran untuk meningkatkan keterampilan proses sains anak usia 5-6 tahun. Peningkatan keterampilan proses sains dapat ditunjukkan melalui mengobservasi, membandingkan, mengklasifikasikan, mengukur dan mengkomunikasikan.
\end{abstract}

Kata Kunci : keterampilan proses sains, pendekatan inkuiri, penelitian tindakan kelas

\section{IMPROVING THE SCIENCE PROCESS SKILLS OF THE CHILDREN THROUGH INQUIRY APPROACH}

\begin{abstract}
Abstract: The purpose of this research is to improve the science process skills of the children aged 5-6 years through inquiry approach at TK Kasih Ibu, South Jakarta. The research conducted in November and December 2012 employed classroom action research within two cycles. Each cycle consisted of planning, acting, observing, and reflecting. The subjects of this research were 12 kindergarten children. The data were collected using test and non test. After the second cycle, the research concluded that the inquiry approach can improve the science basic skills of children aged 5-6 years old. The implication of this research is inquiry approach can be alternative way to improve science process skills of children aged 5-6 years old. The improvement of the science basic science can be demonstrated through observing, comparing, classifying, measuring and communication.
\end{abstract}

Keywwords : science process skills, inquiry approach, classroom action research

\section{PENDAHULUAN}

\section{Latar Belakang}

Sains merupakan ilmu yang penting bagi kehidupan manusia untuk mengenal dan mengelola lingkungan alam disekitarnya. Sebaiknya sains diperkenalkan pada anak sejak usia dini, namun beberapa sekolah belum menerapkan sains dalam pembelajaran ataupun program kegiatan di sekolah. Kurangnya pengenalan sains sejak usia dini juga menyebabkan pembelajaran sains kurang diminati oleh anak pada jenjang sekolah lanjutan. Kebanyakan anak menilai pembelajaran sains sangat sulit dimengerti sehingga keterampilan proses sains anak juga kurang terstimulasi dengan maksimal dan sains sendiri menjadi asing bagi anak usia dini. Hal ini dapat dilihat dari hasil observasi di TK Kasih Ibu, Jakarta Selatan yang menunjukan kurang berkembangnya keterampilan proses sains pada anak. Hasil observasi yang dilakukan menunjukkan pada rendahnya rasa ingin tahu, perhatian dan keterlibatan aktif anak serta penggunaan metode dalam pelaksanaan pembelajaran yang masih bersifat teacher oriented. Hal tersebut terlihat saat pembelajaran sedang berlangsung, yaitu beberapa anak terlihat kurang memperhatikan dan mengobrol dengan temannya yang lain saat guru menjelaskan materi tentang kejadian alam. Hal ini menunjukkan bahwa anak-anak tidak tertarik pada pembelajaran yang dilaksanakan. Selain itu, metode dan media yang digunakan oleh guru juga kurang kreatif. Guru hanya menjelaskan dengan kartu gambar, kemudian guru menanyakan kejadian alam yang anak ketahui. Kegiatan konkret jarang dilakukan guru. Pembelajaran bersifat monoton dan kurang member tantangan pada Jurnal IImiah VISI P2TK PAUD NI - Vol. 8, No.1, Juni 2013 
anak usia dini. Dengan demikian, potensi yang dimilik anak usia dini menjadi tidak berkembang dengan optimal sebagaimana mestinya.

Selain itu, guru masih terpaku untuk mengembangkan kemampuan anak untuk membaca, menulis dan berhitung yang dianggap lebih penting untuk persiapan anak memasuki Sekolah Dasar (SD). Kegiatan menulis dan berhitung menggunakan Lembar Kerja (LK), anak diminta melengkapi kalimat pendek atau menghitung penjumlahan sedangkan kegiatan membaca guru akan menuliskan kalimat pendek di papan tulis lalu meminta anak membacanya bersama-sama.

Untuk memperkenalkan sains pada anak usia dini diperlukan suatu pendekatan yang menarik untuk menemukan apa yang dicari dan dapat memenuhi rasa ingin tahu anak terhadap sesuatu. Peneliti memikirkan suatu pendekatan yang akan digunakan untuk memberi ketertarikan pada pembelajaran sains. Pendekatan yang dipilih ialah pendekatan inkuiri. Pendekatan inkuiri adalah salah satu pendekatan yang memberikan kesempatan langsung pada anak untuk mencari tahu sesuatu hal yang menarik keingintahuannya. Suatu pendekatan pembelajaran yang sistematik yang terdiri dari perencanaan dan pelaksanaan yang terdiri dari empat tahap, yaitu tahap pertama bermain, tahap kedua investigasi, tahap ketiga sebab-akibat dan tahap keempat tantangan. Dengan demikian, pendekatan inkuiri ialah pendekatan untuk mencari suatu jawaban atau penelitian pada suatu masalah secara sistematis. Melalui pendekatan inkuiri diharapkan anak dapat merasakan langsung setiap tahapan dari proses sains secara sistematis dan memberikan pengalaman belajar yang nyata pada anak sehingga pengenalan sains menjadi sangat menarik bagi anak.

\section{Rumusan Masalah}

Berdasarkan uraian diatas, maka peneliti tertarik untuk mengadakan penelitian tentang pendekatan inkuiri yang dapat dijadikan sebagai pendekatan pembelajaran yang menyenangkan untuk menumbuhkan dan menimbulkan ketertarikan anak pada kegiatan percobaan sains pada anak usis 5-6 tahun di TK Kasih Ibu Jakarta Selatan. Untuk itu peneliti akan mengkaji dan menganalisis bagaimana upaya meningkatkan keterampilan proses sains anak usia 5-6 tahun melalui pendekatan inkuiri di TK Kasih lbu, Jakarta Selatan.

\section{Kajian Teori}

\section{a. Keterampilan proses sains}

Dalam pembelajaran sains terdapat tujuan pembelajaran yang terbagi ke dalam dua bagian, yaitu konsep sains dan keterampilan sains. Keterampilan sains sebagai proses kognitif yang untuk mempelajarinya dibutuhkan interaksi dengan konten sains yang dipe- lajari (Harlen dalam Devi, 2010: 2). Dari pernyataan tersebut maka dalam pembelajaran sains diperlukan interaksi langsung dengan hal yang akan anak pelajari, baik berupa benda mati maupun makhluk hidup yang terdapat disekitar anak.

Adapun keterampilan proses sains terdiri dari 5 bagian penting, yaitu: (1) pengamatan (observing), (2) membandingkan (comparing), (3) mengklasifikasikan (classifying), (4) mengukur (meansuring), dan (5) mengkomunikasikan (communicating) (Lind, 1995: 54). Dari pernyataan tersebut, sains dipelajari bukan sekedar mengenal alam tapi lebih menekankan pada tahapan proses yang terjadi untuk menemukan suatu jawaban atau fakta. Dari tahapan proses tersebut diharapkan akan menjadi kegiatan yang bermakna bagi anak sehingga mudah dipahami anak.

Pendapat serupa juga diungkapkan Feldman yang membagi keterampilan proses sains pada anak usia dini menjadi 5 , yaitu observasi, membandingkan, mengklasifikasikan, mengukur dan mengkomunikasikan melalui panca indera (Feldman, 1991: 125). Adapun uraian dari beberapa keterampilan proses sains yaitu sebagai berikut.

Pertama, dalam keterampilan proses sains adalah observasi. Observasi merupakan hal paling utama dalam mempelajari sains, melalui kegiatan ini anak diberikan kebebasan untuk mengeksplorasi dan mencari tahu hal yang berkaitan dengan apa yang akan di teliti. Penggunaan panca indera dalam kegiatan observasi memberi kesempatan anak untuk mencari tahu ukuran, bentuk, warna, tekstur dan halhal lain yang dapat menambah informasi bagi anak untuk menemukan jawaban.

Kedua, yaitu membandingkan (comparing), setelah melakukan observasi anak menemukan beberapa informasi mengenai benda atau hal yang di teliti sehingga secara tidak langsung anak sudah mulai membandingkan dan membedakan. Membandingkan (comparing) adalah kemampuan membandingkan pada anak dapat dilihat dari kemampuan anak dalam melihat persamaan atau perbedaan dari suatu objek. Kegiatan membandingkan ini bermanfaat untuk mengasah keterampilan anak dalam mengamati suatu objek.

Ketiga, adalah mengklasifikasikan (classifying). Untuk melakukan tahapan mengklasifikasi, anak harus membandingkan bagian tertentu yang memiliki kesamaan ciri atau karakteristik tertentu yang hanya dimiliki hal atau benda yang di teliti anak. Mengklasikasikan adalah mengelompokan dan memilah suatu objek berdasarkan kategori tertentu. Pada kegiatan mengklasifikasi anak tidak hanya mengamati tapi 
berpikir untuk mengklasifikasikan benda berdasarkan bentuk, warna, ukuran dan sebagainya.

Keempat, yaitu mengukur (meansuring). Mengukur adalah kemampuan dalam mengkuantifikasi atau menghitung hasil observasi dan dapat berupa angka, jarak, waktu, volume dan suhu, hal yang mungkin bias atau tidak bisa di ukur dengan suatu standar, maka dapat dideskripsikan mengukur adalah kegiatan menghitung atau mendeskripsikan jumlah berdasarkan pengamatan yang telah anak lakukan yang berupa angka, jarak, waktu, volume dan suhu. Kegiatan yang dapat dilakukan pada tahapan ini untuk anak usia dini dapat mengukur besar atau menghitung jumlah bendabenda yang anak temukan.

Kelima, yaitu mengkomunikasikan. Mengkomunikasikan (communicating) adalah kemampuan anak dalam menceritakan proses anak dalam menemukan dan hasil temuannya, pendapat/ide-ide, atau pemecahan masalah yang anak peroleh dari penelitian yang telah anak lakukan. Pada anak usia dini kegiatan mengkomunikasikan dapat berupa lisan, tertulis, gambar dan lain-lain disesuaikan dengan kemampuan anak.

Dari uraian tersebut, kelima tahapan dalam keterampilan proses sains memiliki kegunaan yang saling berkaitan satu sama lain. Diawali dengan observasi yang merupakan tahapan paling utama, pada tahap ini anak di beri kesempatan mencari hal-hal yang berkaitan dengan hal atau benda yang ditelitinya. Setelah melakukan kegiatan observasi anak dapat mengembangkan ke tahapan berikutnya yaitu dalam membandingkan, mengklasifikasi, mengukur dan yang terakhir anak dapat mengkomunikasikan sehingga menjadi tahapan yang utuh dalam mempelajari sains. Melalui keterampilan proses sains diharapkan kegiatan sains dapat menyenangkan dan menjadikan sebagai pengalaman yang nyata untuk anak dalam mengenal hal-hal baru yang terdapat di alam sekitarnya.

b. Pendekatan Inkuiri

Pendekatan inkuiri adalah kegiatan pembelajaran yang menekankan kepada proses mencari dan menemukan (Sanjaya, 2009: 195). Maksud dari pendapat tersebut, bahwa inkuiri merupakan kegiatan yang membuat anak belajar aktif dan terlibat langsung dalam menyelesaikan masalah atau menemukan jawaban dari pembelajaran tersebut (children center). Selain itu, inkuiri merupakan suatu strategi yang berpusat pada anak untuk mencari jawaban suatu pertanyaan melalui prosedur yang jelas (Kourilsky dalam Hamalik, 2008: 220). Maksud dari prosedur di sini, yaitu tahapan untuk mempecahkan suatu pertanyaan atau permasalahan. Artinya, melalui inkuiri anak tidak hanya belajar dengan mandiri dalam menemukan jawaban dengan mengikuti setiap tahapan proses hingga dapat mengambil suatu kesimpulan dari objek yang diteliti anak terutama yang berkaitan dengan sains atau ilmu kealaman.

Dengan demikian, maka pendekatan inkuiri merupakan pendekatan pembelajaran yang sistematis yang menekankan pada proses bagaimana anak menemukan suatu jawaban atau menyelesaikan masalah. Dengan menekankan pada proses menemukan, maka pendekatan inkuiri dapat digunakan dalam mempelajari sains yang juga menekankan pada proses suatu kejadian itu terjadi. Keduanya menjadi kombinasi yang baik untuk dipelajari oleh anak usia dini khususnya anak usia 5-6 tahun, karena pada usia ini anak sudah memiliki kemandirian untuk mengikuti tiap tahapan proses dalam melakukan penelitian pada suatu objek di alam.

Adapun langkah-langkah pendekatan inkuiri lainnya untuk anak usia dini yaitu sebagai berikut: (1) notice, wonder, explore; (2) take a action, extend questions; (3) focus observations, raise question, clarify questions; (4) engage in more focused explorations; (5) bring together data/ideas and formulate patterns and relationships; and (6) share ideas (Worth, 2010).

Berdasarkan pendapat tersebut maka dapat dideskripsikan, bahwa langkah-langkah keterampilan proses sains untuk anak usia dini adalah sebagai berikut: (1) membangkitkan perhatian, keingintahuan dan mencari tahu anak dengan menentukan masalah atau pertanyaan yang menarik untuk dipecahkan bersama; (2) merencanakan tindakan yang perlu dilakukan untuk memecahkan pertanyaan; (3) melakukan observasi dan menjelasan pertanyaan yang di maksud dalam penelitian; (4) fokus dalam melakukan ekplorasi pada masalah yang ingin dipecahkan, pada tahap ini anak juga mulai memikirkan penyebab dari masalah tersebut dari temuannya; dan (5) melakukan diskusi dengan saling menjelaskan penemuan yang masing-masing anak temukan, hal ini menumbuhkan kemampuan sosial yang baik antar anak dalam berkomunikasi dan langkah yang terakhir adalah setelah disimpulkan bersama hasil temuan anak kemudian anak saling berbagi ide dari pemecahan masalah tersebut.

Dengan demikian, diharapkan pendekatan inkuiri dapat dijadikan salah satu pendekatan pembelajaran yang dapat mudah dilakukan oleh anak usia 5-6 tahun khususnya pada pembelajaran sains sehingga dapat anak dapat meningkatkan keterampilan sains. Langkah-langkah yang terdapat dalam pendekatan inkuiri diharapkan menjadi panduan untuk mempermudah guru dalam menggunakan pendekatan ini dalam 
pembelajaran sains. Selain itu, pendekatan inkuiri termasuk pendekatan pembelajaran yang berpusat pada anak, melalui pendekatan ini anak di ajak untuk mandiri dalam melakukan tahapan-tahapan dalam menemukan pemecahan masalah dan berpikir kritis dalam menyampaikan pendapat atau ide. Berdasarkan uraian di atas maka di duga bahwa pendekatan inkuiri dapat meningkatkan keterampilan proses sains pada anak usia 5-6 tahun di TK Kasih Ibu, Jakarta Selatan.

\section{METODE PENELITIAN}

Metode yang digunakan dalam penelitian ini adalah penelitian tindakan kelas (classroom action research). Desain intervensi tindakan atau rancangan siklus penelitian ini menggunakan model Kemmis dan Tanggart. Model penelitian tindakan kelas ini terdiri dari empat langkah, yaitu (1) perencanaan (planning), (2) tindakan (acting), (3) observasi (observing), dan (4) refleksi (reflecting). Kemudian dilanjutkan dengan perencanaan ulang (replanning), pelaksanaan, observasi dan refleksi untuk siklus berikutnya, begitu selanjutnya membentuk suatu spiral.
Penelitian dilakukan di TK Kasih Ibu, Jakarta selatan pada bulan bulan November hingga Desember 2012. Subjek penelitian ini adalah anak usia 5-6 tahun di kelas TK B di TK Kasih Ibu, Jakarta Selatan yang berjumlah 12 anak.

Data penelitian dikumpulkan dengan melakukan observasi. Teknik analisis data yang digunakan dalam penelitian ini adalah dengan analisis deskriptif kualitatif, yaitu mendeskripsikan data-data yang diperoleh dari tahap demi tahap di setiap siklusnya.

\section{HASIL PENELITIAN}

Hasil observasi keterampilan proses sains pada prapenelitian menunjukan bahwa keterampilan proses sains anak usia 5-6 tahun di TK Kasih Ibu, Jakarta Selatan masih kurang terstimulasi secara maksimal. Hal ini dapat dilihat dari masih rendahnya skor yang diperoleh anak dalam kegiatan sains melalui pendekatan inkuiri. Hasil pengamatan yang ditemukan terkait dengan keterampilan proses sains anak di TK Kasih Ibu, Jakarta Selatan selama prapenelitian bahwa masih banyak anak yang belum menunjukan keberanian untuk melakukan pengamatan dan mengungkapkan hasil temuannya.

Tabel 1. Hasil Tindakan Keterampilan Proses Sains

\begin{tabular}{|c|c|c|c|}
\hline \multirow{2}{*}{$\begin{array}{c}\text { No. Respon- } \\
\text { den }\end{array}$} & \multicolumn{3}{|c|}{ Persentase } \\
\cline { 2 - 4 } & Pra Siklus & Siklus 1 & Siklus 2 \\
\hline 1 & $40.8 \%$ & $60.7 \%$ & $80.3 \%$ \\
\hline 2 & $43.3 \%$ & $63 \%$ & $82.3 \%$ \\
\hline 3 & $39.1 \%$ & $55.1 \%$ & $78.3 \%$ \\
\hline 4 & $44.1 \%$ & $65.1 \%$ & $85.7 \%$ \\
\hline 5 & $35.8 \%$ & $51.7 \%$ & $76.5 \%$ \\
\hline 6 & $38.3 \%$ & $58.5 \%$ & $79.5 \%$ \\
\hline 7 & $47.5 \%$ & $73.1 \%$ & $91.8 \%$ \\
\hline 8 & $43.3 \%$ & $68.3 \%$ & $89.5 \%$ \\
\hline 9 & $36.7 \%$ & $53.3 \%$ & $85.1 \%$ \\
\hline 10 & $50 \%$ & $74 \%$ & $94 \%$ \\
\hline 11 & $43.7 \%$ & $60.5 \%$ & $81.1 \%$ \\
\hline 12 & $37.5 \%$ & $52.1 \%$ & $77.7 \%$ \\
\hline Rata-rata & $41.6 \%$ & $61.2 \%$ & $83.4 \%$ \\
\hline & & & \\
\hline
\end{tabular}

Setelah dilakukan perencanaan, tindakan dan pengamatan, peneliti bersama kolaborator mengadakan refleksi tindakan yang telah dilakukan pada siklus I, yaitu sebanyak 7 (tujuh) kali pertemuan. Peneliti dan kolaborator melaksanakan kegiatan dengan pendekatan inkuiri yang disesuaikan dengan perencanaan yang telah dirancang sebelum pelaksanaan kegiatan. Setiap akhir pelaksanaan kegiatan, peneliti bersama kolaborator mengadakan refleksi. Refleksi ini dilakukan dengan tujuan untuk melihat proses pembelajaran pada hari tersebut dan dampak yang terjadi pada anak. Setelah dilaksanakan tindakan pada siklus I, peneliti dan kolaborator memutuskan untuk melanjutkan pada siklus berikutnya. Hal ini dikarenakan keterampilan proses sains anak 5-6 tahun melalui pendekatan inkuiri di TK Kasih Ibu, Jakarta Selatan belum mengalami peningkatan sesuai dengan skor yang disepakati peneliti dan kolaborator yaitu sebesar $71 \%$.

Hasil refleksi secara kuantitatif dari observasi siklus I menunjukan bahwa keterampilan proses sains anak hanya mengalami peningkatan sebesar $19.6 \%$ dari perolehan nilai keterampilan proses sains pada pra-penelitian $41.6 \%$ yaitu sebesar $61.3 \%$ pada siklus I, sedangkan prosentase yang seharusnya diperoleh adalah minimal sebesar $71 \%$. Hal ini disebabkan karena terbatasnya waktu dalam pemberian tindakan dan kurangnya kesempatan anak untuk melakukan interaksi langsung dengan lingkungan alam yang akan dipelajari.

Pelaksanaan kegiatan pada siklus II hampir 
memiliki kesamaan pada pelaksanaan kegiata di siklus I, namun banyaknya tindakan yang diberilkan pada siklus II sebanyak 5 kali pertemuan. Hal ini disebabkan karena pada pelaksanaan kegiatan pada siklus I belum mengembangkan secara maksimal aspekaspek mengenai keterampilan proses sains. Pada siklus II ini, peneliti memberikan kesempatan pada anak untuk melakukan eksplorasi pada lingkungan alam dan mengemukakan hasil temuannya. Setelah dilaksanakan tindakan pada siklus II, peneliti dan kolaborator memutuskan untuk tidak melanjutkan pada siklus selanjutnya. Hal ini dikarenakan keterampilan proses sains anak melalui pendekatan inkuiri pada pelaksanaan tindakan siklus II telahh menunjukan peningkatan yang signifikan.

Pada beberapa aspek, seperti kemampuan dalam mengobservasi dengan salah satu panca indera, kemampuan dalam mengemukakan hasil temuan dan kemampuan dalam mengklasifikasikan benda yang memiliki kesamaan warna sudah mengalami peningkatann pada siklus I yang lalu. Pada siklus II ini menunjukkan peningkatan yang lebih baik dibandingkan dengan siklus sebelumnya, kemampuan lainnya seperti kemampuan membanding dan mengukur juga menunjukan peningkatan.

Hasil refleksi secara kuantitatif dari observasi siklus II menunjukan bahwa keterampilan proses sains mengalami peningkatan mencapai $83.4 \%$ dari keterampilan proses sains pada siklus I sebesar $61.2 \%$ dan pada pra-penelitian sebesar $41.6 \%$. Kenaikan yang diperoleh melebihi skor minimal, yaitu $71 \%$ yang merupakan hasil kesempakatan peneliti dan kolaborator.

Hasil refleksi secara kuantitatif dan kualitatif membuat peneliti dan kolaborator sepakat untuk tidak melanjutkan penelitian ke siklus berikutnya, karena telah tercapainya keterampilan proses sains anak usia 5-6 tahun melalui pendekatan inkuiri di TK Kasih Ibu, Jakarta Selatan. Peningkatan tersebut dapat dilihat pada kemampuan anak dalam mengamati objek alam yang sedang dipelajari, anak menggunakan panca inderanya dalam melakukan kegiatan mengamati. Kemudian kemampuan dalam membandingkan dan mengklasifikasikan objek yang telah diamati menunjukan peningkatan, kemampuan dalam mengukur juga terlihat saat anak mengukur tinggi tanaman kecambah dan menghitung jumlah bagian-bagian tanaman. Anak juga menunjukan kemampuannnya dalam mengkomunikasikan hasil temuannya, anak menceritakan proses penemuan dan apa hasil temuan yang diperolehnya pada peneliti ataupun teman-temannya, anak juga mengemukakan pendapatnya saat kegiatan diskusi dan mengkomunikasikan hasil temuannya melalui gambar ataupun prakarya lainnya.

Rata-rata peningkatan keterampilan proses sains pada siklus I adalah $61.2 \%$. Hal tersebut terlihat dari hasil perhitungan observasi sebelum dan sesudah pemberian tindakan pada siklus I, sedangkan untuk rata-rata persentase pada siklus II adalah sebsar $83.4 \%$. Hal tersebut terlihat dari hasil perhitungan observasi sebelum dan sesudah pemberian tindakan pada siklus II.

Peneliti dan kolaborator merasa bahwa peningkatan yang dihasilkan pada akhir siklus II ini sudah signifikan, karena prosentase kenaikan sudah berada di atas batas minimum yang telah disepakati dan ditentukan oleh peneliti bersama kolaborator, yaitu sebesar $71 \%$. Dengan demikian peneliti menghentikan pemberian perlakuan sampai dengan siklus II, karena peningkatan yang diharapkan sudah mencapai skor yang disepakati bahkan melebihi skor tersebut.

Apabila dilihat dari hasil skor di atas, keterampilan proses sains anak akan terus berkembang optimal apabila diberikan stimulasi secara berkesinambungan dengan jangka waktu yang optimal. Namun, hal tersebut harus tetap diperhatikan dan disesuaikan dengan karakteristik perkembangan anak usia dini, karena tidak semua anak pada usia yang sama akan memiliki kemampuan yang sama juga. Pemberian kegiatan pembelajaran dengan pendekatan inkuiri merupakan pendekatan pembelajaran yang baru bagi anak dalam meningkatakan keterampilan proses sains.

Kegiatan pembelajaran dengan pendekatan inkuiri dapat dikatakan sebagai kegiatan yang cocok untuk mempelajari sains, melalui pendekatan inkuiri ini keterampilan proses sains terlihat meningkat dengan baik. Hal tersebut senada dengan pendapat Seefeldt \& Jobling mengemukakan inkuiri adalah An inquiry approach is the most current approach to learning science and relateds to children undertaking investigations to answer their own questions. Hal tersebut dimaksudkan bahwa pendekatan inkuiri merupakan suatu pembelajaran mengenai investigasi mendalam pada suatu topik pembelajaran. Keterampilan proses sains dapat dipelajari secara mendalam dengan menggunakan pendekatan inkuiri, karena melalui pendekatan ini anak diberi kesempatan untuk melalukan interaksi langsung dengan lingkungan alam yang akan dipelajari dan mengajak anak untuk belajar mandiri untuk memecahkan masalah atau menemukan jawaban.

Alasan pendekatan inkuiri dapat meningkatkan keterampilan proses sains juga dikarenakan pendekatan inkuiri memiliki beberapa tahapan yang membantu anak mengembangkan keterampilan proses sains. Tahap-tahapnya adalah sebagai berikut pertama 
anak diajak untuk berdiskusi tentang hal yang ingin anak ketahui tentang objek yang akan dipelajari dan peneliti juga dapat menanyakan hal-hal yang anak ketahui berkaitan dengan objek yang anak dipelajari. Kemudian tahapan kedua membuat perencanaan bersama apa yang perlu dilakukan untuk memecahkan masalah tentang objek yang telah disepakati untuk dipelajari pada hari tersebut, tahapan ketiga peneliti bersama anak melakukan pengamatan pada objek alam yang dipelajari. Saat melakukan observasi anak diberi kesempatan untuk mengamati objek tersebut secara mendetail, peneliti hanya menjadi fasilitator dan mengarahkan anak dengan memberikan pertanyaanpertanyaan yang dikembangkan dari objek yang sedang diobservasi anak. Saat observasi peneliti menanyakan perbandingan dan melakuakn pengklasifikasian objek yang diobservasi anak serta mengukurnya. Pada tahapan terakhir anak berdiskusi untuk saling sharing hasil temuan yang masing-masing anak temukan dan anak diajak menceritakan temuannya secara lisan dan anak juga dapat mengkomunikasikan hasil temuannya secara tertulis dengan membuat gambar atau prakarya lainnya.

Berdasarkan uraian di atas, maka dapat dikatakan bahwa pendekatan inkuiri dapat meningkatkan keterampilan proses sains anak dengan tahapantahapan yang terdapat dalam pendekatan inkuiri. Tahapan tersebut memberikan kesempatan pada anak untuk melakukan eksplorasi pada objek yang akan dipelajari dan secara mandiri anak mengembangkan kemampuannya untuk memecahkan masalah atau menemukan jawaban dari objek alam yang sedang dipelajari sehingga dapat meningkatkan keterampilan proses sains anak. Keseluruhan aspek dalam keterampilan proses sains ini mengalami peningkatan selama 12 kali pemberian perlakuan pada anak dalam 2 siklus. Hal ini dapat terlihat pada kemampuan anak mengobservasi, membandingkan, mengklasifikasi, mengukur dan mengkomunikasikan yang menunjukan peningkatan yang signifikan.

\section{PENUTUP}

\section{Kesimpulan}

Penelitian keterampilan proses sains anak usia 5-6 tahun telah dilaksanakan sesuai dengan permasalahan yang terjadi di lapangan. Prosentase yang diperoleh dari prapenelitian adalah sebesar $41.6 \%$ dan prosentase yang diperoleh dari siklus I mencapai skor $61.2 \%$ dan persentase tersebut belum mencapai skor minimal yang disepakati oleh peneliti dan kolaborator. Sehingga perlu dilakukan pemberian tindakan ulang di siklus II. Dari pemberian tindakan tersebut diperoleh prosentase siklus II yang mencapai $83.4 \%$ dan skor ini melebihi skor yang telah disepakati oleh peneliti dan kolaborator, yaitu sebesar $71 \%$.

Berdasarkan data kualitatif terlihat adanya peningkatkan keterampilan proses sains anak usia 5-6 tahun melalui pendekatan inkuiri. Dengan menggunakan kegiatan pembelajaran melalui pendekatan inkuiri, anak diberi kesempatan untuk melakukan secara mandiri tiap tahapan pada objek yang sedang dipelajari hingga anak menemukan jawaban dan pemecahan masalah dari objek yang diteliti anak. Berdasarkan hal tersebut dapat disimpulkan bahwa pendekatan inkuiri dapat meningkatkan keterampilan proses sains anak usia 5-6 tahun di TK Kasih Ibu, Jakarta Selatan.

\section{Saran}

Pertama, bagi guru pendekatan inkuiri untuk mengembangkan keterampilan proses sains anak dapat menjadi bahan pembelajaran yang menarik bagi anak. Guru dapat memberikan pembelajaran mengenai lingkungan alam atau dan sains yang dilakukan melalui pendekatan inkuiri sehingga pembelajaran yang diberikan tidak hanya kegiatan membaca, menulis, dan berhitung. Anak juga dapat mengembangkan kemampuannya yang lain. Bagi mahasiswa PG PAUD, dapat memberikan referensi dan menambah wawasan bahwa dalam pembelajaran sains melalui pendekatan inkuiri merupakan salah satu contoh pendekatan pembelajaran yang dapat diberikan kepada anak usia dini dan mampu meningkatkan keterampilan proses sains anak. Kedua, bagi orang tua, para orang tua dapat menyadari bahwa sebenarnya keterampilan proses sains juga merupakan salah satu kemampuan yang penting untuk dipelajari oleh anak. Orang tua dapat memberikan pengetahuan sains kepada anak melalui lingkungan alam yang ada disekitar rumahnya. Ketiga, bagi peneliti, dapat melakukan penelitian yang berkaitan dengan kegiatan peningkatan keterampilan proses sains anak melalui pendekatan inkuiri bagi anak usia dini.

\section{DAFTAR PUSTAKA}

Devi, P.K. (2010). Keterampilan proses dalam pembelajaran IPA untuk guru SD. Jakarta: Pusat
Pengembangan dan Pemberdayaan Pendidik dan Tenaga Kependidikan IImu Pendidikan 
Alam.

Feldman, J.R. (1991). A survival guide for the preschool teacher. New York: The Center for Applied Research in Education.

Hamalik, O. (2008). Proses belajar mengajar. Jakarta: Bumi Aksara.

Lind, K.K. (1995). Math and science for young children. New York: Delmar Publishers.
Sanjaya, W. (2009). Strategi pembelajaran berorientasi estandar proses pendidikan. Jakarta: Kencan Worth, K. (2010). Science in early childhood classrooms: Content and process. SEED paper, diakses dari halaman website http://ecrp.uiuc. edu/beyond/seed/worth.html pada tanggal 3 November 2013. 